\title{
MEASURED STRATIGRAPHIC SECTION, LOWER NANUSHUK FORMATION (ALBIAN), ARC MOUNTAIN ANTICLINE, NANUSHUK RIVER, ALASKA
}

David L. LePain, Nina T. Harun, and Russell A. Kirkham

Preliminary Interpretive Report 2021-6

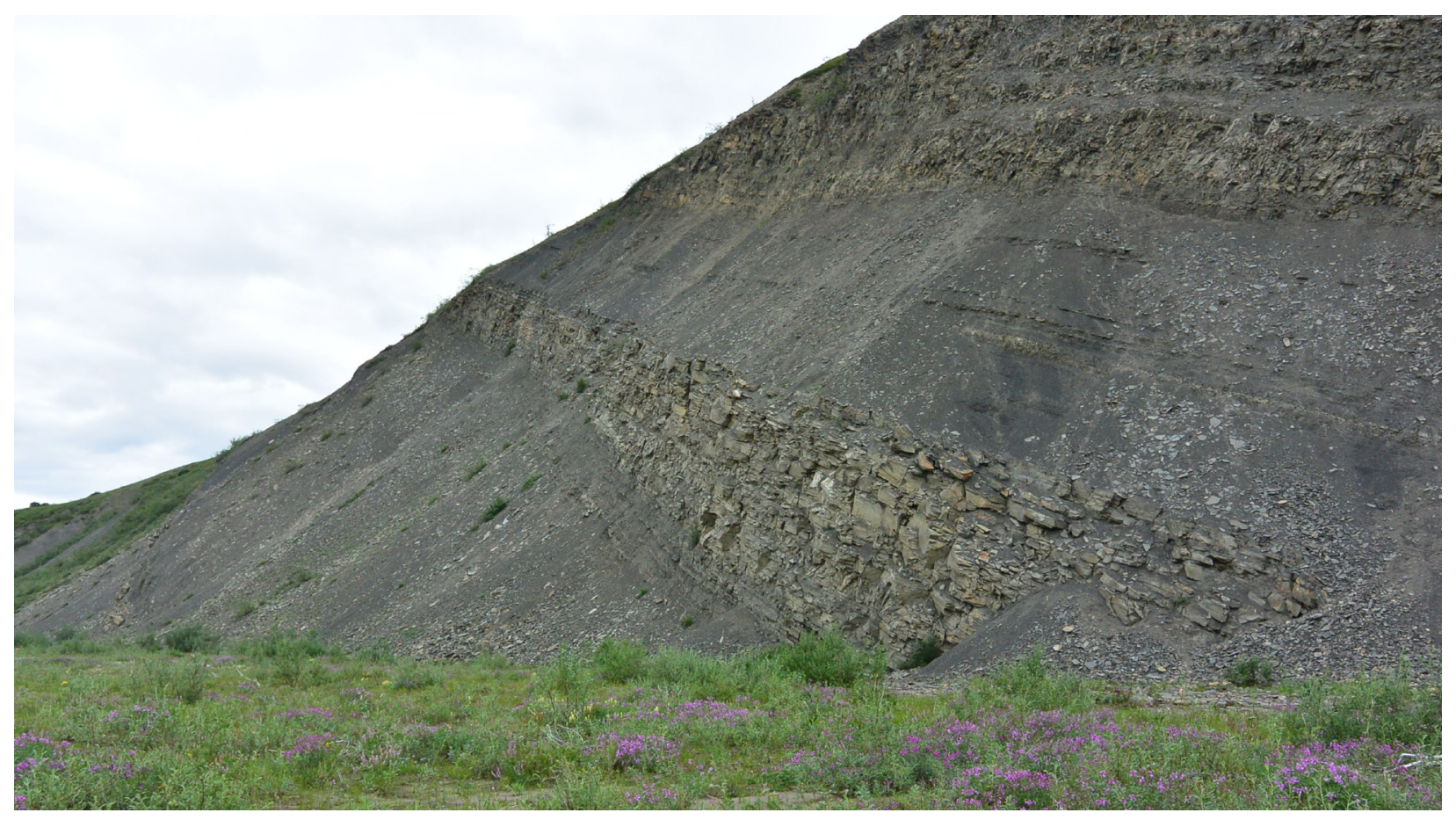

View toward the east-northeast showing the upper part of the third shallow marine parasequence (PS3) in the Nanushuk Formation exposed on the south limb of Arc Mountain anticline, along the east side of the Nanushuk River. Abundant hummocky and swaley cross-stratification demonstrate a storm wave influence on delta front deposits at this location. See text and sheet 1 for details.

This publication has not been reviewed for technical content or for conformity to the editorial standards for DGGS.

2021

STATE OF ALASKA

DEPARTMENT OF NATURAL RESOURCES

DIVISION OF GEOLOGICAL \& GEOPHYSICAL SURVEYS
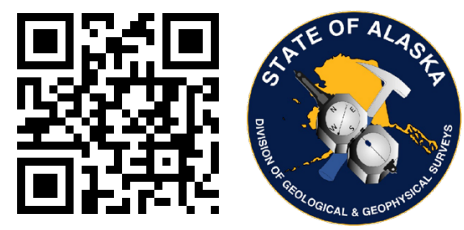
STATE OF ALASKA

Mike Dunleavy, Governor

DEPARTMENT OF NATURAL RESOURCES

Corri A. Feige, Commissioner

\section{DIVISION OF GEOLOGICAL \& GEOPHYSICAL SURVEYS}

Steve Masterman, State Geologist \& Director

Publications produced by the Division of Geological \& Geophysical Surveys are available to download from the DGGS website (dggs.alaska.gov). Publications on hard-copy or digital media can be examined or purchased in the Fairbanks office:

Alaska Division of Geological \& Geophysical Surveys (DGGS)

3354 College Road | Fairbanks, Alaska 99709-3707

Phone: 907.451 .5010 | Fax 907.451.5050

dggspubs@alaska.gov|dggs.alaska.gov

\section{DGGS publications are also available at:}

Alaska State Library, Historical

Collections \& Talking Book Center

395 Whittier Street

Juneau, Alaska 99801

Alaska Resource Library and

Information Services (ARLIS)

3150 C Street, Suite 100

Anchorage, Alaska 99503

\section{Suggested citation:}

LePain, D.L., Harun, N.T., and Kirkham, R.A., 2021, Measured stratigraphic section, lower Nanushuk Formation (Albian), Arc Mountain anticline, Nanushuk River, Alaska: Alaska Division of Geological \& Geophysical Surveys Preliminary Interpretive Report 2021-6, 15 p., 1 sheet. https://doi.org/10.14509/30762
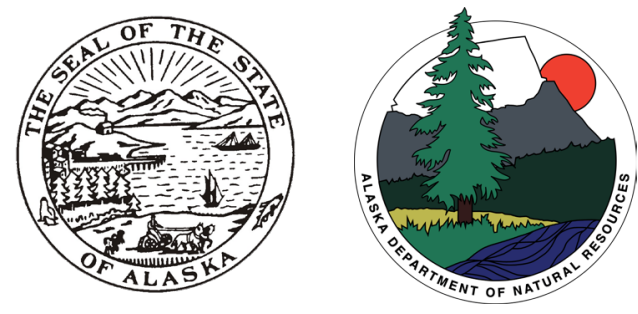


\title{
MEASURED STRATIGRAPHIC SECTION, LOWER NANUSHUK FORMATION (ALBIAN), ARC MOUNTAIN ANTICLINE, NANUSHUK RIVER, ALASKA
}

\author{
David L. LePain', Nina T. Harun', and Russell A. Kirkham²
}

\section{INTRODUCTION}

LePain and others (2009) presented a detailed analysis of Nanushuk depositional systems in the eastern part of its outcrop belt. They presented detailed snippets of larger measured sections in the body of the report to illustrate facies associations and included more complete, although simplified, versions of measured stratigraphic sections from key locations in an appendix. The purpose of this brief report is to present a detailed measured section through the lower marine part of the Nanushuk exposed on the south limb of Arc Mountain anticline (figs. 1-3 and sheet 1). Shoreface and delta front parasequences documented in this report serve as outcrop analogues for marine parasequences in the lower part of the formation in an exploration fairway that extends from a short distance south of Umiat to the Beaufort Sea and from an ultimate Nanushuk shelf margin east of the Colville River to the Chukchi Sea coast. This report is timely as several large oil discoveries have been announced in the past eight years in the eastern part of this fairway in shoreface-delta front reservoirs near the base of the Nanushuk. Not surprisingly, the area is the focus of significant exploration interest and development activities are underway in at least two of the recent discoveries (Willow and Pikka; see fig. 1). Detailed measured sections from other important Nanushuk outcrops will be released in forthcoming reports. The reader is referred to Decker (2018) and Houseknecht (2019) for discussions of the Nanushuk's petroleum potential. Figure 4 is a modified version of the simplified complete Arc Mountain measured section published by LePain and others (2009) showing the stratigraphy covered in the detailed section (sheet 1).

\section{SUMMARY OF STRATIGRAPHIC ORGANIZATION}

The lower marine part of the Nanushuk Formation is relatively well exposed on the south limb of Arc Mountain anticline, along the east bank of the Nanushuk River near Arc Mountain (fig. 2). Uplift and erosion has resulted in removal of the Nanushuk near the anticline's axial trace, where the upper part of the Torok Formation is present beneath a nearly continuous cover of tundra vegetation (Mull and others, 2009). Chips of silty shale from the Torok are present in frost boils, squirrel burrows, bear diggings, and in a few very small exposures among willows on the east wall of the river valley. The Torok-Nanushuk contact is not exposed, but is inferred at the base of the first sandstone body (figs. 4 and 5, sheet 1). On the south limb, beds dip from 20 to 23 degrees toward due south. The lower marine Nanushuk grades up-section toward the south to marginal marine facies and, continuing southward toward the axis of Arc Mountain syncline, to a thick succession of tundra-covered alluvial flood basin deposits and resistant fluvial channel belt deposits (LePain and others, 2009). The nonmarine section is estimated to be at least $300 \mathrm{~m}$ thick and is truncated by the modern erosion surface. The depositional thickness of the Nanushuk in this area is unknown. The composite section provides a minimum thickness estimate of $770 \mathrm{~m}$.

\footnotetext{
${ }^{1}$ Alaska Division of Geological \& Geophysical Surveys, 3354 College Road, Fairbanks, Alaska 99707: david.lepain@alaska.gov

${ }^{2}$ Alaska Division of Mining, Land and Water, 550 W. 7th Ave, Suite 1360, Anchorage, AK 99501
} 


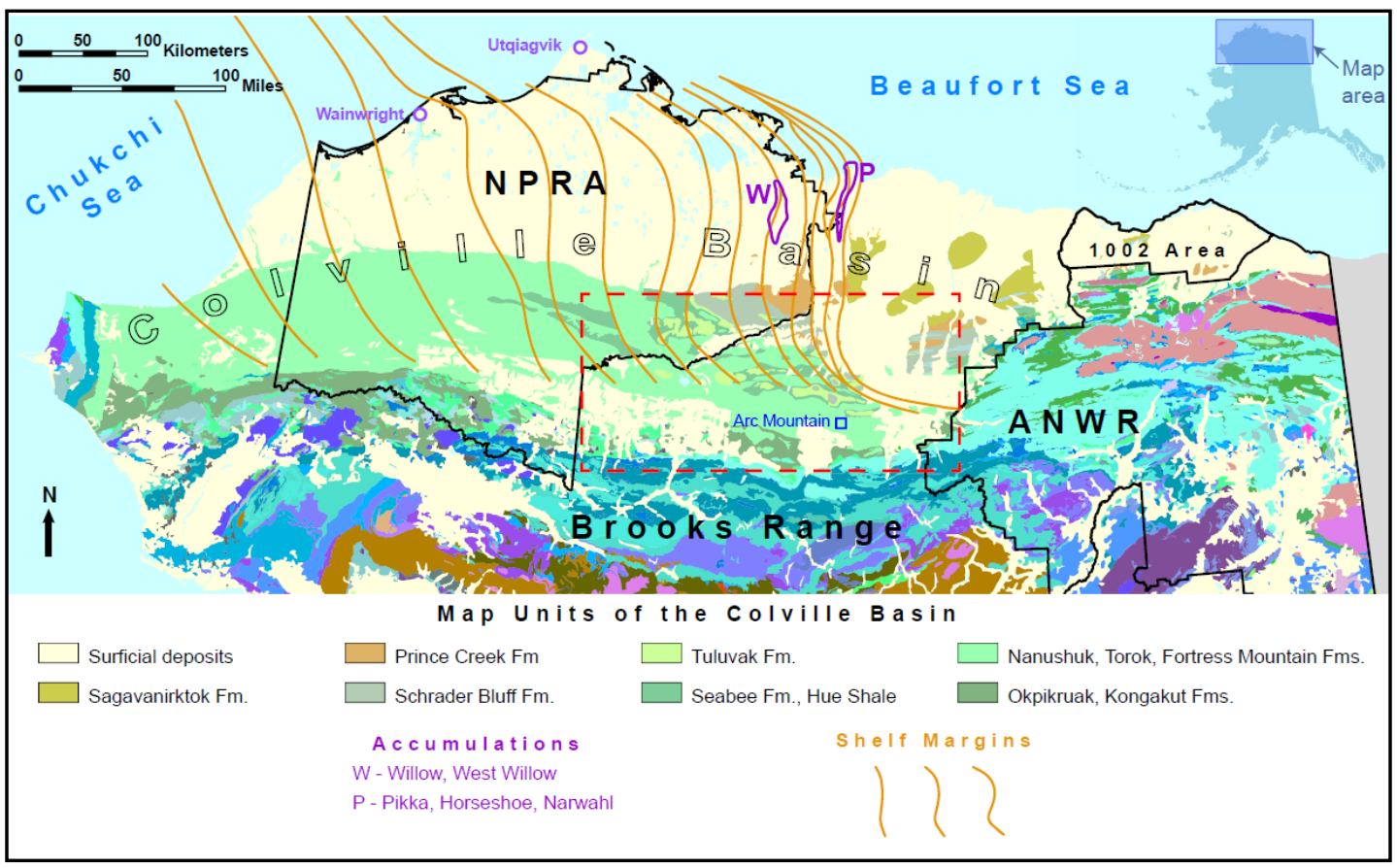

Figure 1. Simplified geologic map of northern Alaska showing the location of Arc Mountain study area (blue square; fig. 2). Purple polygons show the approximate locations of oil discoveries at Willow (W) and Pikka (P). Nanushuk lowstand shelf margins are from Houseknecht (2019). Geology from Wilson and others (2015).

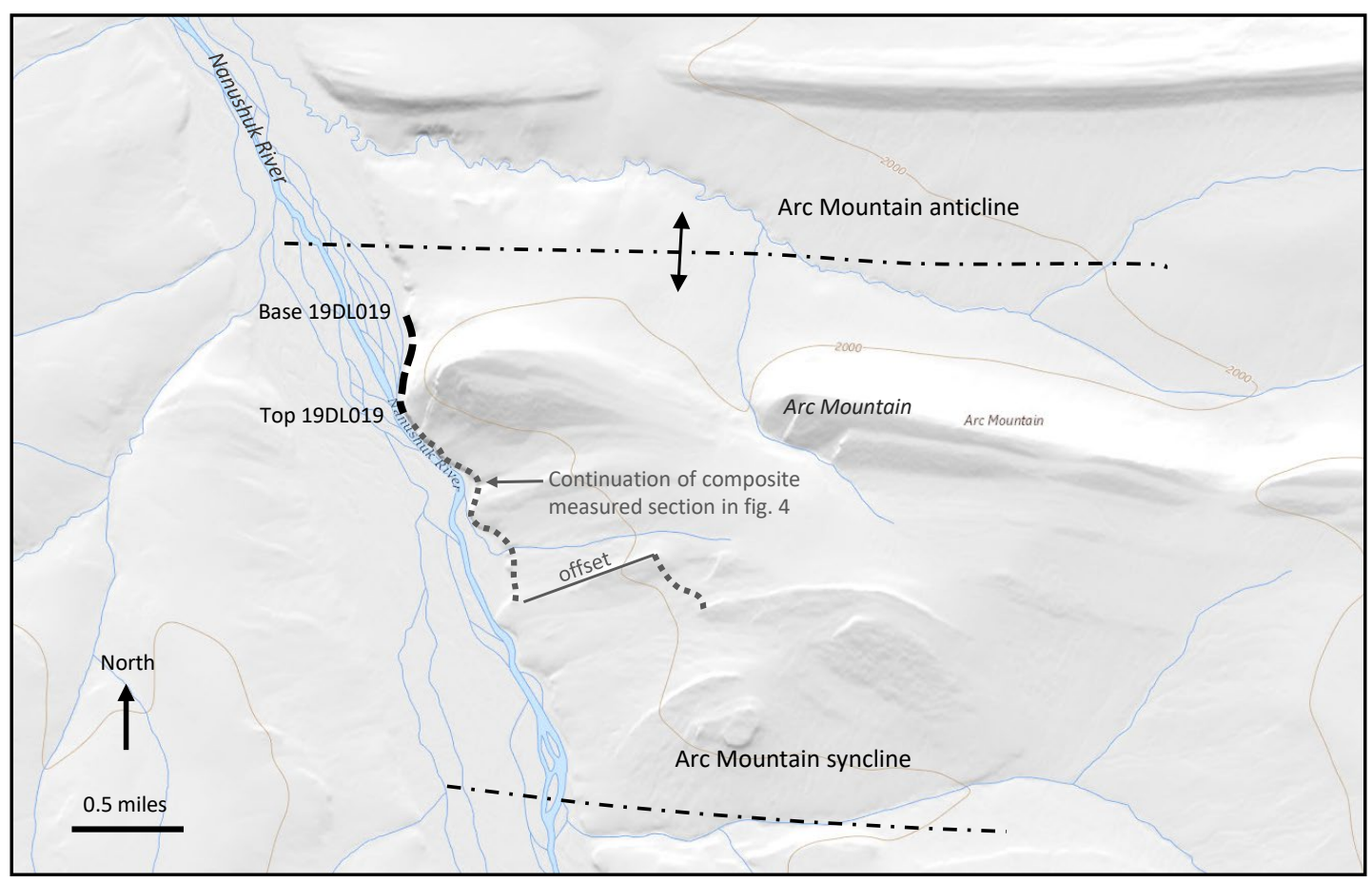

Figure 2. Shaded relief map showing the Arc Mountain study area and location of the measured section addressed in this report (dashed black line). The dashed black line and the dotted gray line show the composite section measured in 1999 (shown in fig. 4). The composite section consists of five segments measured by different geologists and stitched together by the first author. The lower marine part was re-measured in 2019 to provide a continuous section with a uniform and detailed graphic log. The axial traces of Arc Mountain anticline and syncline are approximated from Mull and others (2009). Map from U.S. Geological Survey National Map. 


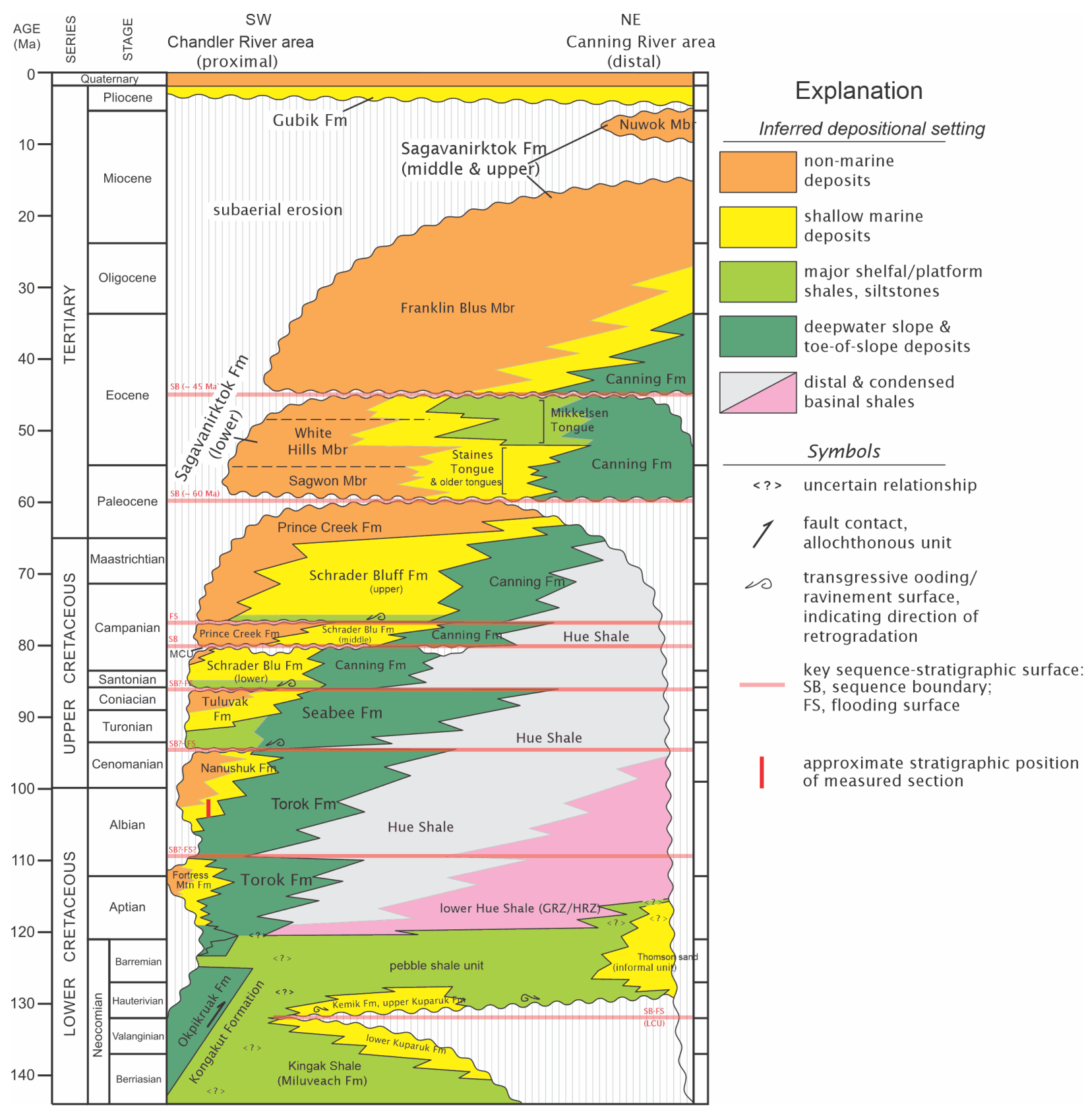

Figure 3. Simplified chronostratigraphic column and generalized sequence stratigraphy of the Brookian Sequence. The solid red line shows the approximate stratigraphic position of the detailed measured section on sheet 1 . Modified from Decker and others (2009).

The succession of alternating alluvial floodbasin and fluvial channel belt deposits described above appear absent on the north limb of Arc Mountain anticline, where the unit forms a prominent dip slope and exposures consist of a limited thickness of frost-shattered sandstone. Approximately $12 \mathrm{~km}$ west of the Nanushuk River, a nonmarine succession of floodbasin and coarse-grained fluvial channel deposits are exposed on the north limb. Finzel (2004) conducted an architectural analysis of nonmarine Nanushuk deposits in the vicinity of the Kanayut River, including the north limb of Arc Mountain anticline. 


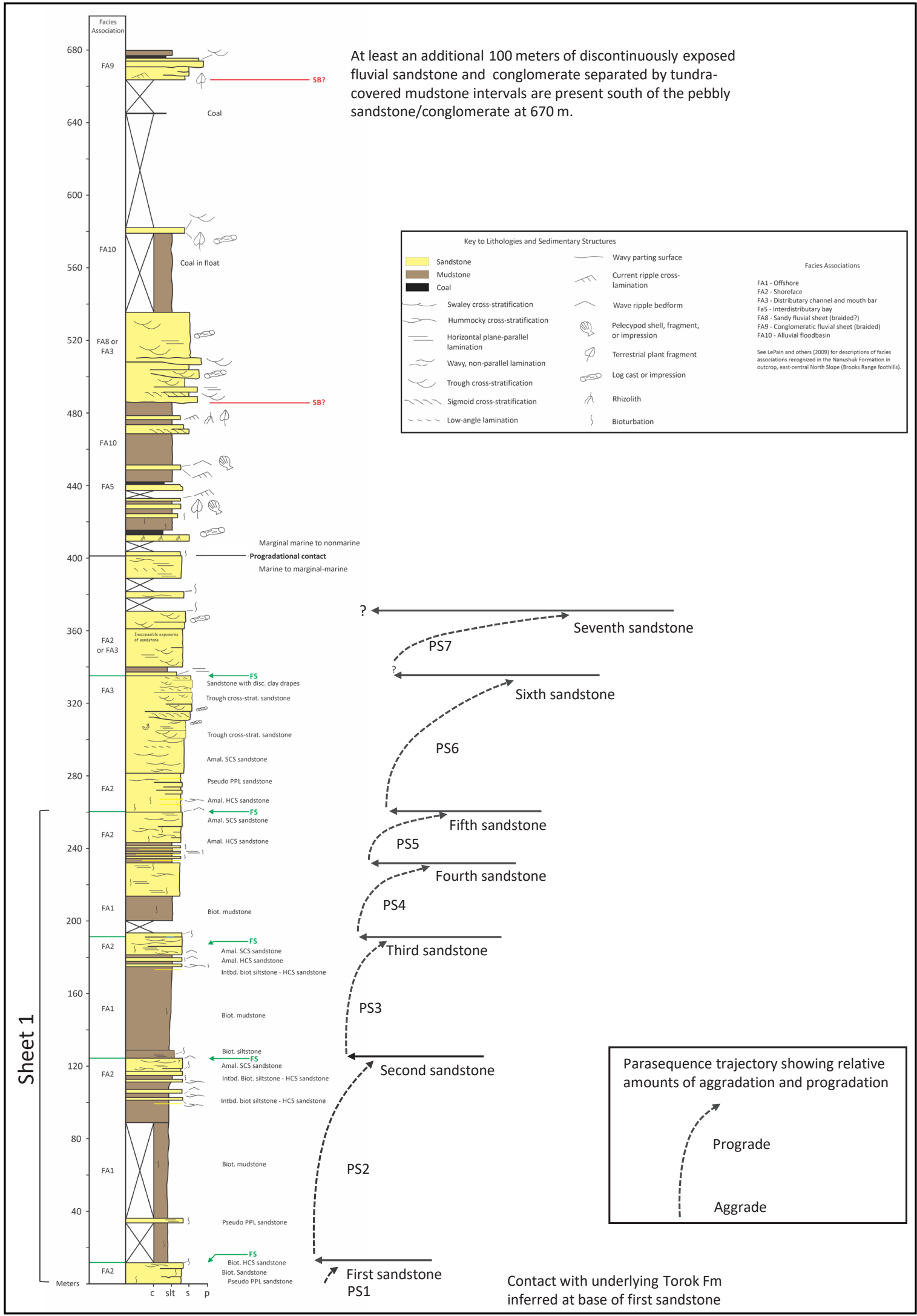

Figure 4. Simplified version of a composite measured section through the Nanushuk Formation on the south flank of Arc Mountain anticline. The detailed section shown on sheet 1 corresponds to the lower $260 \mathrm{~m}$ of the composite section. The contact with the Torok Formation is placed at the base of the first sandstone body deposited in a shallow marine setting (sheet 1). Modified from LePain and others (2009). 


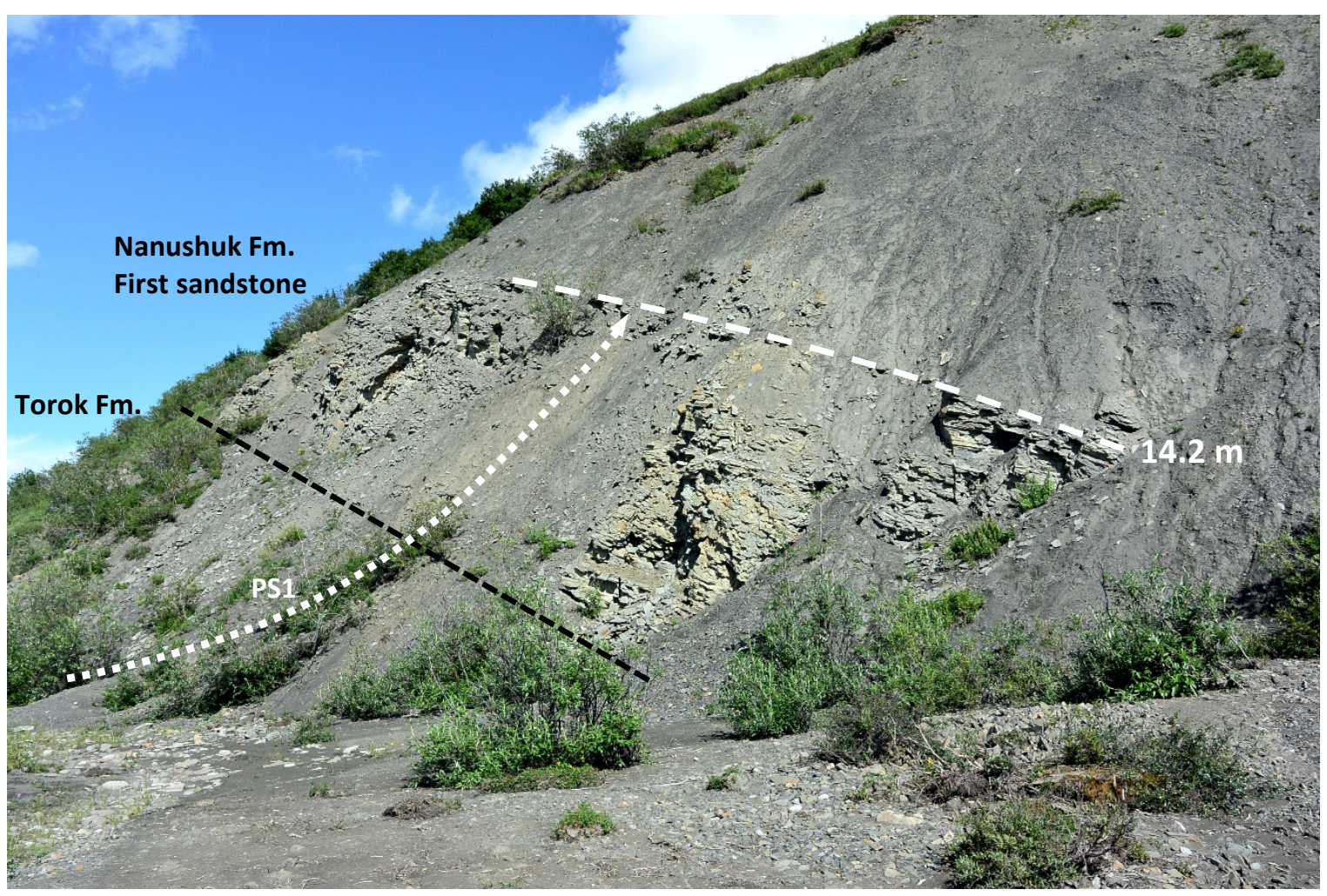

Figure 5. Photograph showing the lower 16 meters of the detailed measured section shown on sheet 1 (see left edge of photomosaic at bottom of sheet; PS1). This interval is informally referred to herein as the first sandstone and corresponds to the upper part of the first shallow marine parasequence in the Nanushuk Formation at this location. The amalgamated sandstones comprising this outcrop are highly bioturbated (mixed Cruziana-Skolithos ichnofacies) and include a few beds with preserved plane-parallel horizontal laminae and hummocky cross-stratification. Physical sedimentary structures and bioturbation suggest deposition in a lower shoreface setting.

The exposed lower marine Nanushuk at Arc Mountain consists of at least seven shallow marine parasequences, with each representing an episode of shoreline progradation (labeled PS1 through PS7 on figure 4; only PS1 through the lower part of PS5 are shown on sheet 1). Each parasequence is capped by a succession of amalgamated sandstone, labeled first sandstone through the seventh sandstone on fig. 4 (sheet 1 ). Each successively higher parasequence is thinner and includes slightly more proximal facies. The decrease in thickness is largely the result of a progressive decrease in the thickness of mudstone forming the lower part of each parasequence, with PS5 and PS6 consisting of amalgamated sandstone successions. These characteristics define a progradational parasequence stacking pattern that culminates in distributary mouth bar and channel deposits at the top of PS6 and 7 and, ultimately, in the thick succession of nonma-rine deposits extending up-section toward the axis of Arc Mountain syncline (visible in upper right corner of photomosaic at bottom of sheet 1).

Sedimentary structures preserved in sandstones in PS1 through the lower part of PS6 provide evidence for deposition in storm-wave-modified shallow marine and shore zone settings. Amalgamated sandstone beds at the top of PS1 are moderately to completely bioturbated (BI 3-6; figs. 5 and 6A, sheet 1), but locally include intervals of sparsely to moderately bioturbated sandstone (BI 2 to 3 ) with hummocky cross-stratification (HCS; fig. 6B). HCS is prominent in sandstones throughout the upper part of PS2 

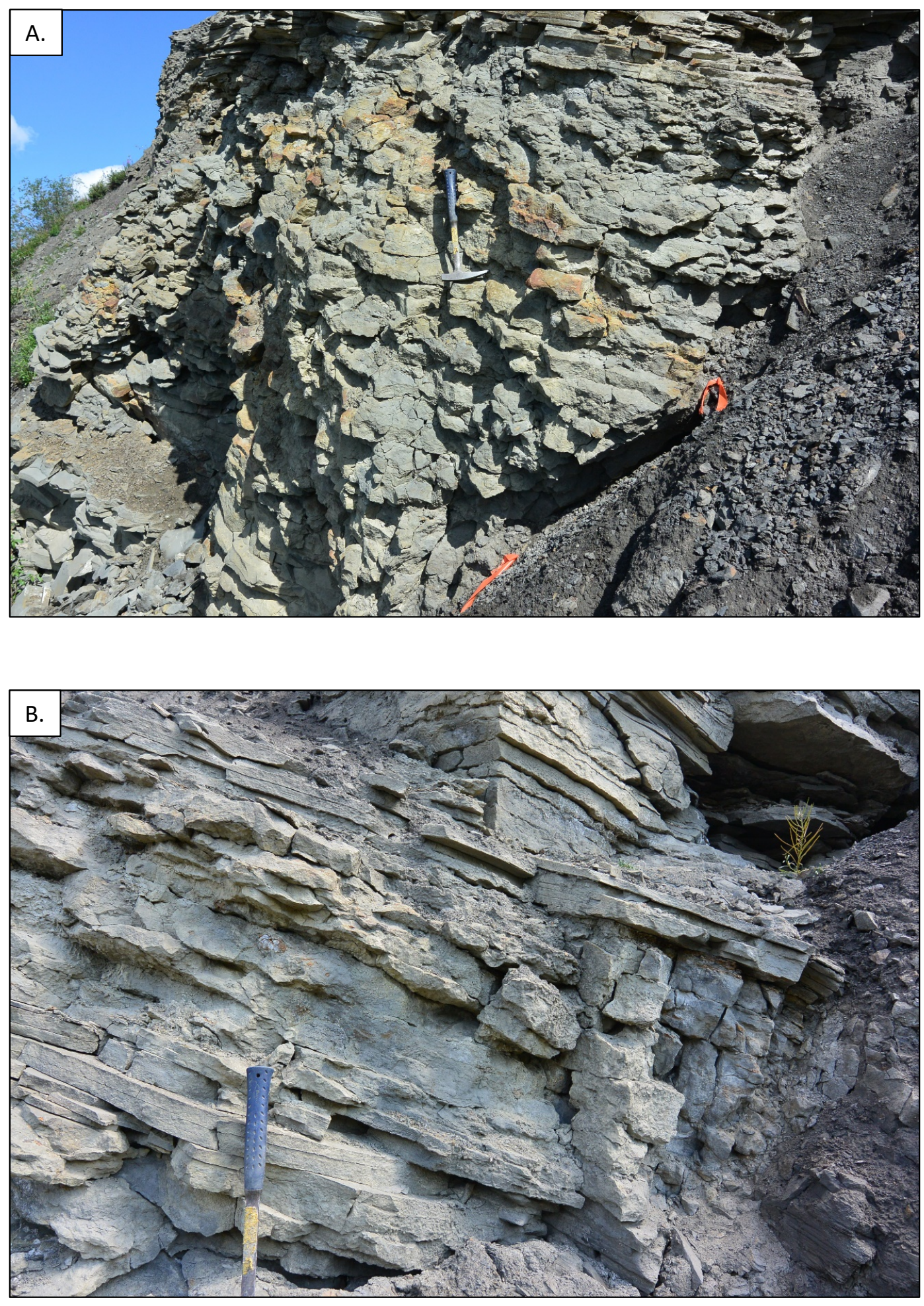

Figure 6. Selected photographs showing key characteristics of the first sandstone (at top of PS1). A. Highly bioturbated sandstone from 5 to $6.5 \mathrm{~m}$. The rock hammer in the upper center of the outcrop is $41 \mathrm{~cm}$ long. View toward northeast. B. Interbedded sparsely and highly bioturbated sandstone from approximately 10 to $11.5 \mathrm{~m}$. The sandstone bed behind the hammer handle displays wavy, non-parallel lamination interpreted as hummocky cross-stratification. Horizontal, plane-parallel laminated sandstone is visible near the top of the photograph. This bedding motif is typical of lower shoreface (distal wave-modified delta-front) deposits in the Nanushuk Formation. Visible part of hammer is approximately $36 \mathrm{~cm}$ long. 
(figs. 7, 8A and 8C). A common vertical sequence of sedimentary structures observed in many sandstone beds in these parasequences consists of the following - basal scour surface $\rightarrow \pm$ massive sandstone with or without mudstone rip-up clasts $\rightarrow \pm$ horizontal plane-parallel to wavy laminae $\rightarrow \pm \mathrm{HCS} \rightarrow \pm$ moderately bioturbated wave-ripple cross-laminated cap (fig. 8A and 8C). Figures 9, 10A-C, 11A-C and 12A-C illustrate examples from PS3 through PS5. In addition to these structures, swaley cross-stratification (SCS) is present near the top of PS2 and is common in PS3, PS4, PS5 and the lower part of PS6 (fig. 12C). These beds are interpreted as storm deposits (tempestites) and the parasequences they comprise are the deposits of prograding storm-influenced shorefaces associated with storm wave-influenced delta lobes. The succession of sedimentary structures outlined here in a single sandstone bed is well documented in the literature on shallow marine storm deposits, for example Dott and Bourgeois (1982), Walker and others (1983), Duke and others (1991), and Myrow and Southard (1996), to name only a few. In PS6 the shoreface succession is truncated by a distributary channel and mouth bar succession (fig. 4; not shown on sheet 1).

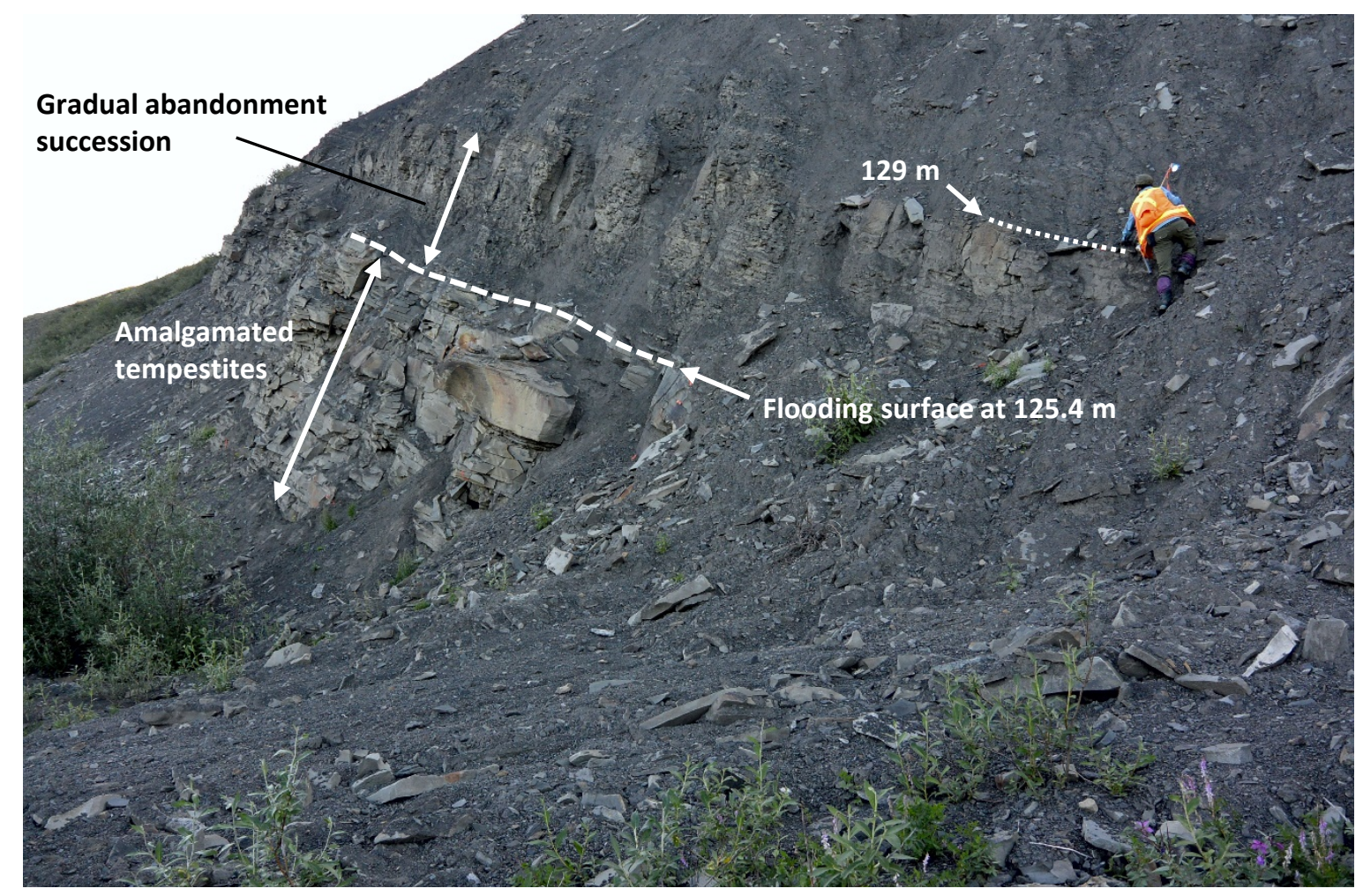

Figure 7. View toward the northeast showing the interval from approximately 106 to $132 \mathrm{~m}$ in the detailed measured section shown on sheet 1 (see photomosaic at bottom of sheet; PS2). The sand-rich part of this interval $(110.2$ to $125.4 \mathrm{~m}$ ) is informally referred to herein as the second sandstone (at top of PS2). The second sandstone records deposition in a lower shoreface setting and most of the sandstone beds in it are storm deposits. The bioturbated upper part of each bed commonly extends downward into, or through, a wave ripple cross-laminated upper division. The dashed white line marks a flooding surface at $125.4 \mathrm{~m}$ separating amalgamated sandstone storm deposits below (uppermost PS2) from interbedded siltstone and muddy sandstone above (lowermost PS3). The geologist's left hand is resting on a second flooding surface (white arrow and dotted white line at $129 \mathrm{~m}$ ) that separates proximal offshore transition deposits below from distal offshore transition-shelf deposits above (see fig. 13 and text for details). The abundance of HCS throughout the upper part of this parasequence indicates deposition in a high-energy shoreface setting (wave-modified delta-front). 

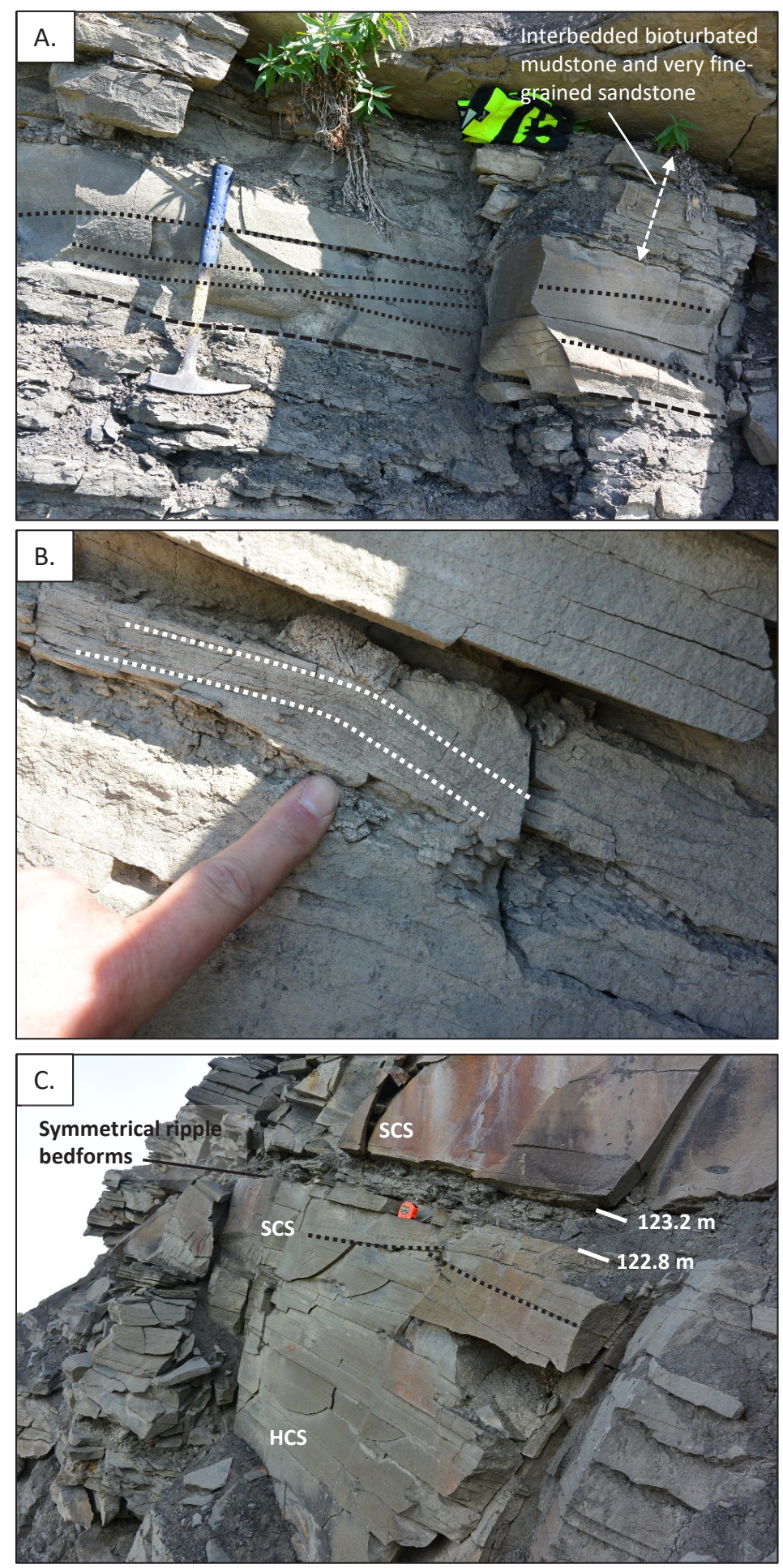

Figure 8. Photographs showing selected features of the second sandstone (PS2).

A. Tempestite bed between $111 \mathrm{~m}$ and 112 $m$ consisting of very fine-grained, hummocky cross-stratified sandstone (dotted lines trace selected laminae defining hummocks and swales). Nearly symmetrical wave-ripple bedforms cover part of the upper surface of the bed. The hammer head is resting on interbedded bioturbated mudstone and very fine-grained sandstone and the end of the handle is resting on similar deposits above the $\mathrm{HCS}$ bed. The hammer is $42 \mathrm{~cm}$ long.

B. Vertical aggrading wave-ripple cross-stratification preserving the ripple bedform at $112.2 \mathrm{~m}$. This sandstone is interpreted as the product of a minor storm event in which sand rapidly settled out of suspension while being reworked by shoaling waves.

C. A thick bed of hummocky cross-stratified and swaley cross-stratified sandstone (SCS) from approximately $121 \mathrm{~m}$ to $122.8 \mathrm{~m}$. The upper surface of the bed is covered with wave-ripple bedforms generated during the late waning stage of the storm event that deposited the sandstone bed. Bioturbated mudstone with thin sandstone interbeds deposited during fairweather conditions separates this tempestite bed from the next younger storm-generated sandstone bed (base at $123.2 \mathrm{~m}$ ). 


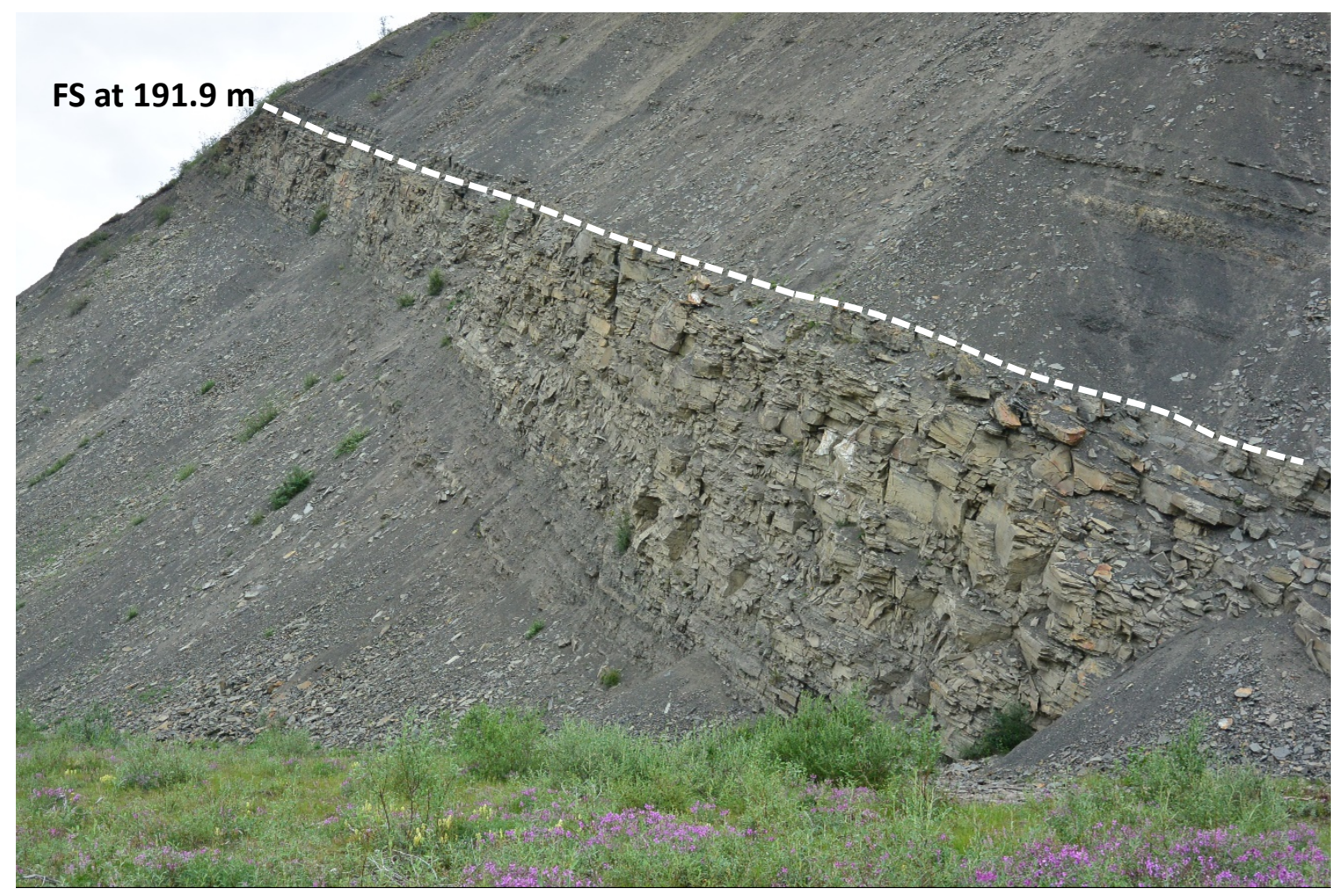

Figure 9. View toward the northeast showing the interval from approximately $165 \mathrm{~m}$ to $206 \mathrm{~m}$ in the detailed measured section shown on sheet 1 (see photomosaic at bottom of sheet; PS3). The sand-rich part of this interval $(177.7 \mathrm{~m}$ to $191.9 \mathrm{~m})$ is informally referred to herein as the third sandstone. This interval corresponds to the sandy upper part of a parasequence recording deposition in a high-energy lower shoreface setting (wave-modified delta front). The interval from $181.6 \mathrm{~m}$ to $191.9 \mathrm{~m}$ includes amalgamated event deposits, consisting primarily of horizontal, plane-parallel laminated very fine-grained sandstone. This sandstone differs from the second sandstone in having less HCS and SCS. This difference is attributed to deposition in a more proximal setting in which storm events were dominated by upper flow-regime plane bed conditions. The apparent thickening of the sand body toward the lower right of the photograph is largely due to a foreshortening effect.

Most marine parasequences at Arc Mountain (PS1 through PS4) are bounded by flooding surfaces, above which there is an abrupt change from shallow marine sandstone to mudstone deposited in offshore shelf or offshore transition settings. PS2 is notably different in that the flooding surface at its top is overlain by nearly three meters of highly bioturbated proximal offshore transition deposits that are, in turn, overlain by distal offshore transition-shelf deposits (figs. 7 and 13A-B). This succession indicates a slowdown in sedimentation and gradual abandonment of the shoreface, in contrast to the abrupt flooding and rapid decrease in sedimentation evident in the other parasequences at this location.

Marine parasequences in the lower part of the Nanushuk Formation at Arc Mountain are interpreted as storm wave-modified delta lobes and are similar to some wave-modified delta front deposits in the Dunvegan Formation (Bhattacharya and Walker, 1991) and the Ferron Sandstone (Ryer and Anderson, 2004). Wave-modified deltas typically have fewer distributary channels and include delta front deposits that are similar to shoreface successions in non-deltaic settings. Depending on the direction of wave approach and position along the delta front relative to distributary channels, the delta front region in wave-dominated settings can closely resemble a shoreface (Bhattacharya, 2006). 

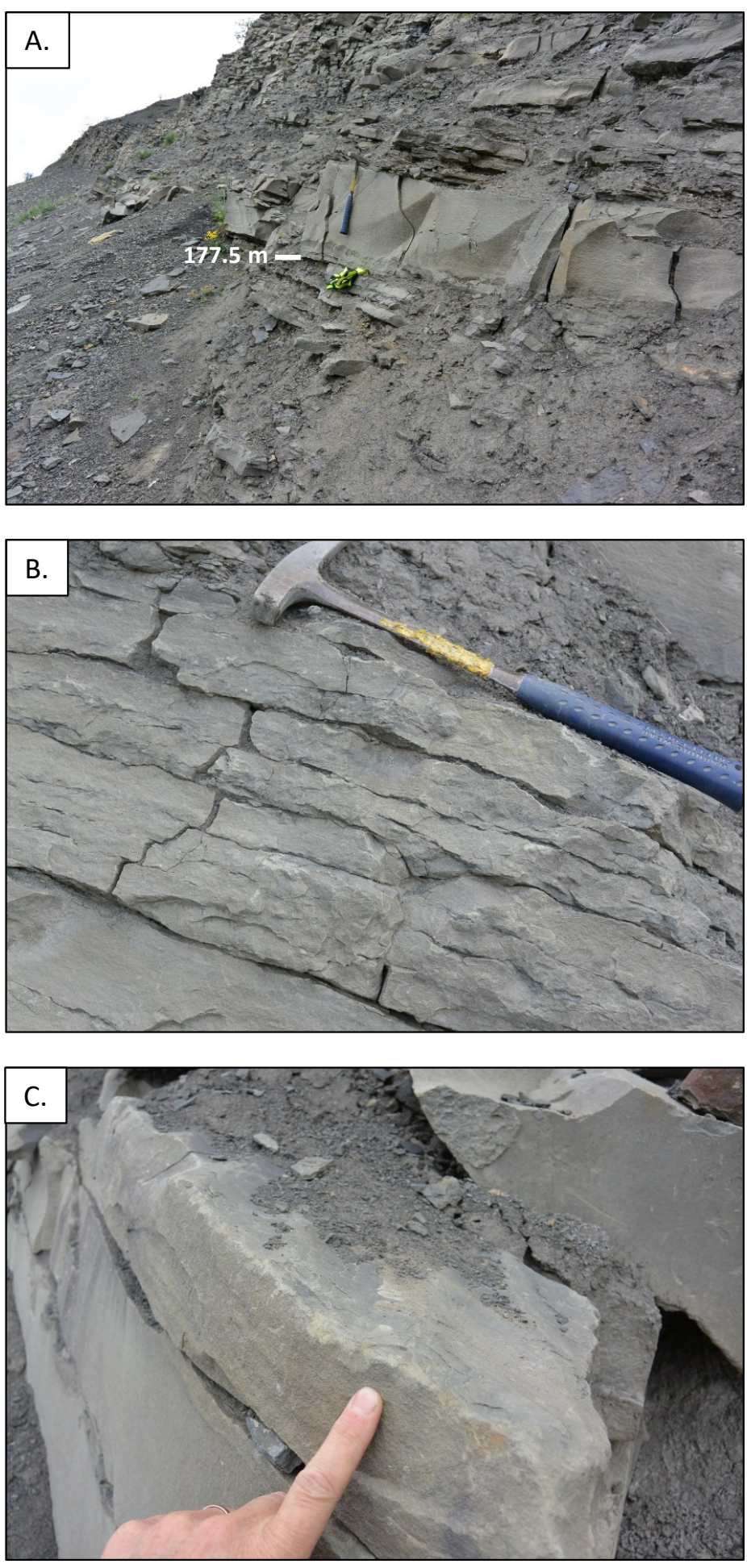

Figure 10. Photographs showing selected features of the third sandstone (PS3). A. Interbedded moderately to intensely bioturbated mudstone and low to moderately bioturbated sandstone from approximately $176 \mathrm{~m}$ to $179 \mathrm{~m}$. The hammer head is resting on the upper surface of a swaley cross-stratified sandstone bed, the lower 90 percent of which appears unbioturbated $(\mathrm{BI})$ and the upper 10 percent is moderately bioturbated (BI 3). Interbedded mudstone and sandstone was deposited in an offshore transition to distal lower shoreface setting. The hammer in the center of the photograph is $42 \mathrm{~cm}$ long. B. Bioturbated sandstone at $183.6 \mathrm{~m}$. The parting surfaces are interpreted as amalgamation surfaces. The hammer is $42 \mathrm{~cm}$ long. C. Slightly asymmetrical ripple bedforms capping a sandstone bed at $191.9 \mathrm{~m}$. The underlying bed appears structureless. 

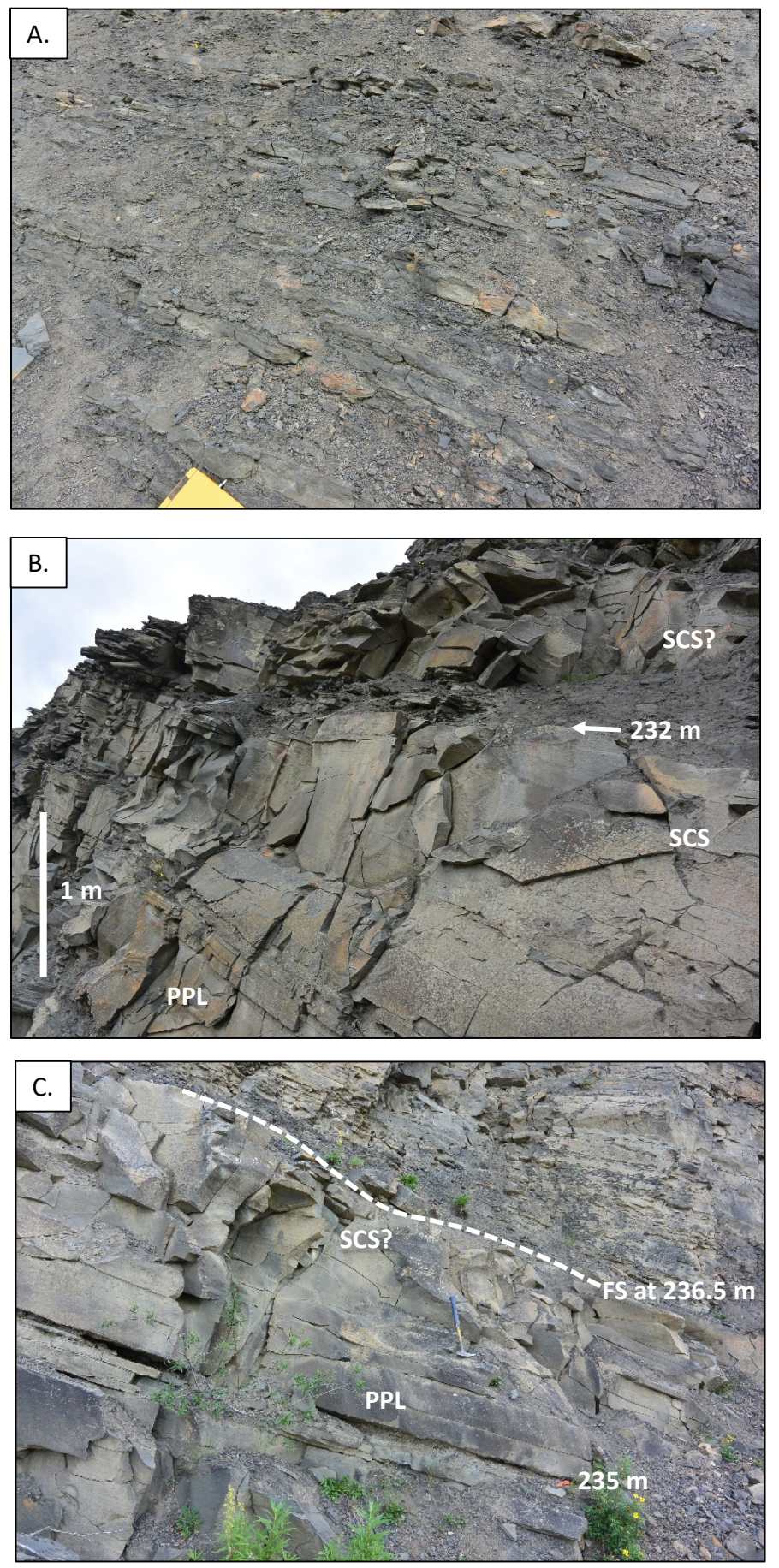

Figure 11. Photographs showing selected features of the fourth sandstone (PS4). A. Interbedded argillaceous siltstone and very fine-grained sandstone from approximately $211 \mathrm{~m}$ to $213 \mathrm{~m}$. Siltstones are moderately to intensely bioturbated (BI 3-5) and sandstones are sparsely to moderately bioturbated (BI 1-3). Interbedded siltstone and sandstone were deposited in an offshore transition or prodelta setting. Black rectangle on edge of yellow notebook is 5 $\mathrm{cm}$ long. B. Amalgamated sandstone beds from approximately $230 \mathrm{~m}$ to $232 \mathrm{~m}$. Sandstone immediately below the contact with siltstone (white arrow) includes low-relief concave-upward laminae interpreted as swaley cross-stratification (SCS). Vertical white bar is $1 \mathrm{~m}$ long. C. Thick bed of very fine-grained sandstone at the top of the fourth sandstone body. The base of the bed includes horizontal, plane-parallel laminae (PPL) and the upper part is probably swaley cross-stratified (SCS?). A flooding surface marks the top of the parasequence at $236.5 \mathrm{~m}$ (FS). The upper contact is covered with wave ripple bedforms. The hammer to the right of the photo-center is $42 \mathrm{~cm}$ long. 

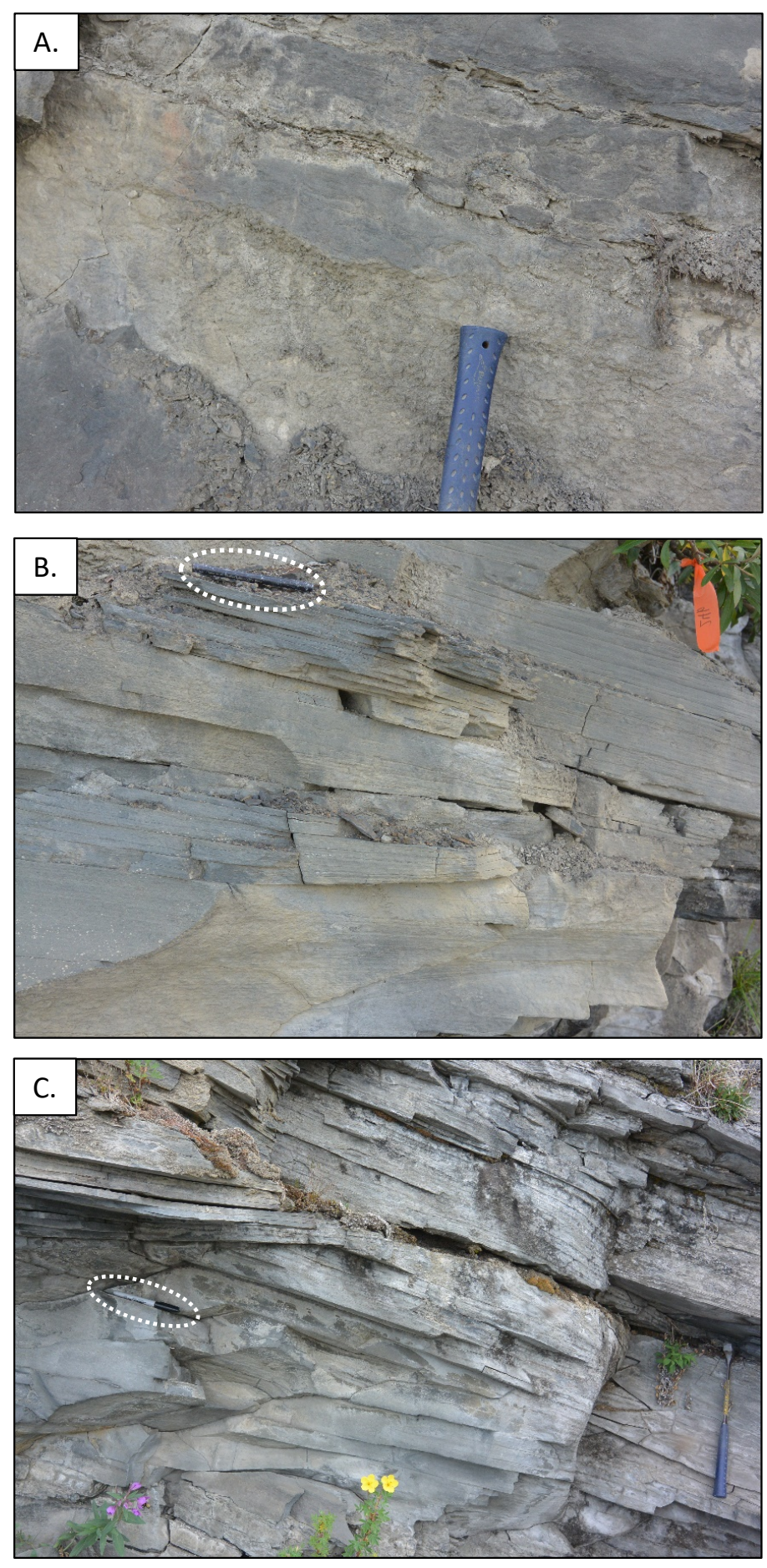

Figure 12. Photographs showing selected features of the succession above the fourth sandstone (lower part of PS5). A. Interbedded sandy siltstone-silty sandstone and very fine-grained sandstone at approximately $240.5 \mathrm{~m}$. Muddy lithologies are highly to intensely bioturbated (BI 4-5) and sandstones are sparsely to moderately bioturbated (BI 2-3). Horizontal plane-parallel lamina, wavy laminae, and HCS are common in sandstones. The degree of bioturbation overall suggests deposition in a wave-modified proximal prodelta setting. Visible part of hammer handle is $20 \mathrm{~cm}$ long. B. Thick bed of very fine-grained, hummocky cross-stratified sandstone at $245.5 \mathrm{~m}$. Note the subtle concave-upward geometry of laminae near the bottom of the photograph and very subtle convex-upward geometry in the upper center of the photograph. These features are interpreted as HCS. The eraser enclosed by the dotted white oval is $12.5 \mathrm{~cm}$ long and the orange flagging is $3 \mathrm{~cm}$ wide. C. Sandstone bed with SCS at $248 \mathrm{~m}$. The succession between approximately $244.4 \mathrm{~m}$ and the top of the measured section is interpreted as distributary mouth bar and distal distributary channel deposits. The sharpie enclosed by the dotted white oval is $13.5 \mathrm{~cm}$ long and the hammer (near right edge of photograph) is $42 \mathrm{~cm}$ long. 

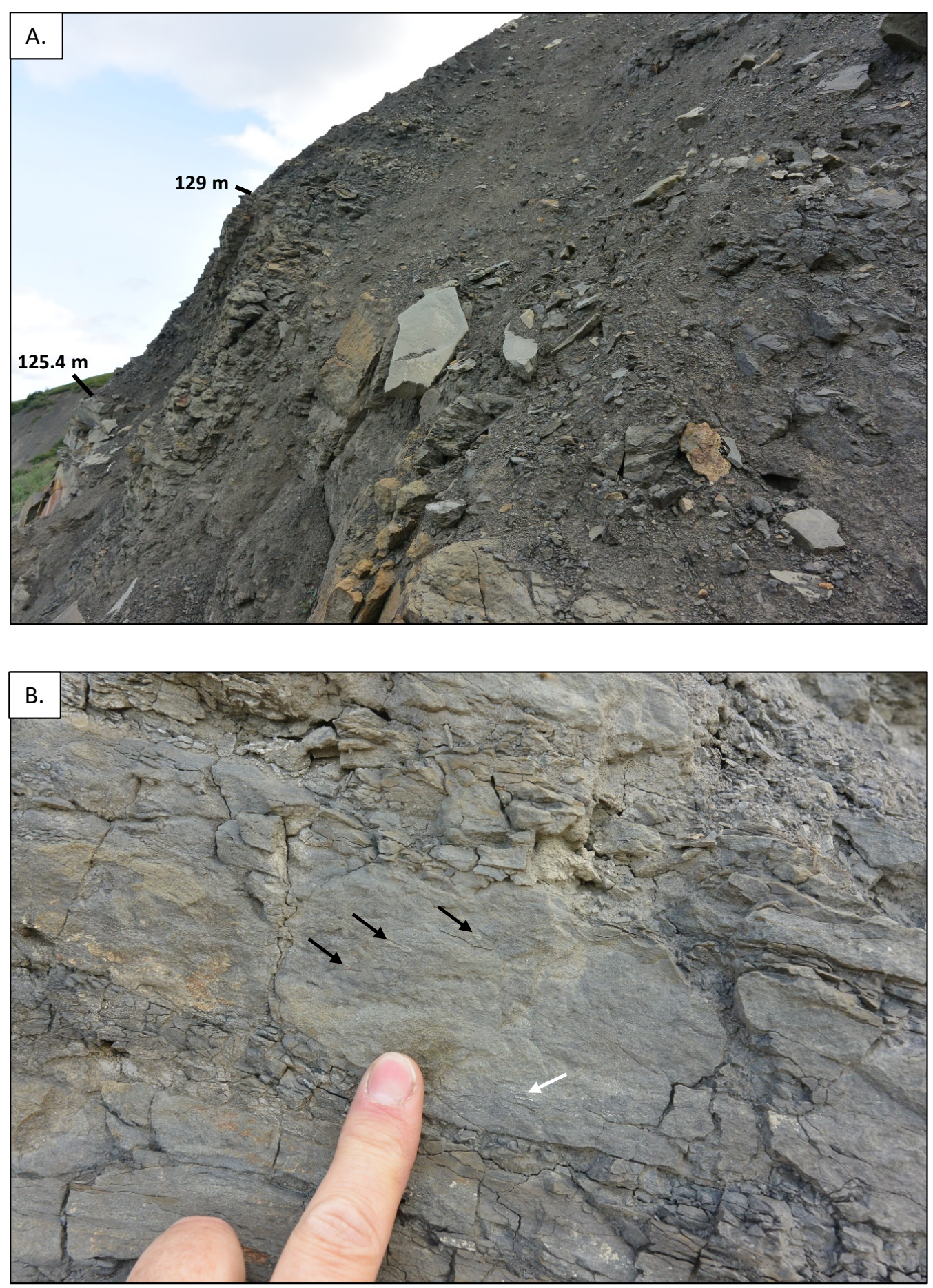

Figure 13. Photographs showing the gradual abandonment succession capping the second sandstone. A. Interbedded moderate to intensely bioturbated mudstone and silty very fine-grained sandstone (BI 3-5) from 125.4 $\mathrm{m}$ to $129 \mathrm{~m}$. The break in slope at $129 \mathrm{~m}$ marks the contact between the gradual abandonment succession and overlying distal offshore transition-shelf deposits. B. Bioturbated sandstone bed (BI 3-4) with possible Schaubcylindrichnus (black arrows) and Palaeophycos (white arrow) burrows at approximately $127 \mathrm{~m}$. 


\section{HYDROCARBON SHOWS}

No hydrocarbon shows have been encountered in the Nanushuk at Arc Mountain. This is in contrast to the Nanushuk approximately $22 \mathrm{kms}$ ( 13.6 miles) north of Arc Mountain anticline, at the east end of Rooftop Ridge anticline, where several strong hydrocarbon shows are present in the lower $80 \mathrm{~m}$ of the formation and at least one in the upper $200 \mathrm{~m}$ (LePain and others, 2021).

\section{ACKNOWLEDGMENTS}

We thank Gil Mull for making us aware of the Arc Mountain exposure at the start of the 1999 field season, and Rocky Reifenstuhl, Jim Clough, Paul McCarthy, and Tim Ryherd for help in measuring the composite section. Trystan Herriott (DGGS) reviewed a draft of this report and made suggestions for its improvement. Our work on the Nanushuk was funded by an industry consortium that most recently includes ConocoPhillips, Chevron, and Oil Search. Many companies that contributed financial support in the past no longer exist (Anadarko, ARCO, etc.). Additional support was provided by the U.S. Geological Survey and the State of Alaska.

\section{REFERENCES}

Bhattacharya, J.P., 2006, Deltas, in Posamentier, H.W., and Walker, R.W., eds., Facies Models Revisited: SEPM Special Publication 84, p. 237-292.

Bhattacharya, J.P., and Walker, R.G., 1991, Facies and facies successions in river- and wave-dominated depositional systems of the Upper Cretaceous Dunvegan Formation, northwestern Alberta: Bulletin of Canadian Petroleum Geology, p. 165-191.

Decker, P.L., LePain, D.L., Wartes, M.A., Gillis, R.J., Mongrain, J.R., Kirkham, R.A., and Shellenbaum, D.P., 2009, Sedimentology, stratigraphy, and subsurface expression of upper Cretaceous strata in the Sagavanirktok River area, east-central North Slope, Alaska: Alaska Division of Geological \& Geophysical Surveys, 3 sheets. https://doi.org/10.14509/30156

Decker, P.L, 2018, Nanushuk Formation discoveries: World-class exploration potential in a newly proven stratigraphic play, Alaska North Slope: Discovery Thinking Forum, AAPG ACE, Salt Lake City, Utah.

Dott, R.H., and Bourgeois, J., 1982, Hummocky stratification: Significance of its variable bedding sequences: Geological Society of America Bulletin, v. 93, p. 663-680.

Duke, W.L., Arnott, R.W.C., and Cheel, R.J., 1991, Shelf sandstones and hummocky cross-stratification: New insights on a stormy debate: Geology, v. 19, p. 625-628.

Finzel, E.S., 2004, Architectural analysis and fold geometry of syntectonic fluvial conglomerate in the Nanushuk Formation, Brooks Range foothills, Alaska: University of Alaska Fairbanks, M.S. thesis, 230 p., illust., maps.

Houseknecht, D.W., 2019, Petroleum systems framework of significant new oil discoveries in a giant Cretaceous (Aptian-Cenomanian) clinothem in Arctic Alaska: AAPG Bulletin, v. 103, p. 619-652.

LePain, D.L., Kirkham, R.A., and Montayne, Simone, 2021, Measured stratigraphic section, Nanushuk Formation (Albian-Cenomanian), Nanusuk River (Rooftop Ridge), Alaska: Alaska Division of Geological \& Geophysical Surveys Preliminary Interpretive Report 2021-5, 8 p., 1 sheet. https://doi.org/10.14509/30744

LePain, D.L., McCarthy, P.J., and Kirkham, R.A., 2009, Sedimentology and sequence stratigraphy of the middle Albian-Cenomanian Nanushuk Formation in outcrop, central North Slope, Alaska: Alaska Division of Geological \& Geophysical Surveys Report of Investigation 2009-1 v. 2, 76 p., 1 sheet. https://doi. $\operatorname{org} / 10.14509 / 19761$ 
Mull, C.G., Harris, E.E., Delaney, P.R., and Swenson, R.F., 2009, Geology of the Cobblestone Creek-May Creek area, east-central Brooks Range Foothills, Alaska: Alaska Division of Geological \& Geophysical Surveys Preliminary Interpretive Report 2009-5, 40 p., 1 sheet, scale 1:63,360. https://doi.org/10.14509/19661

Myrow, P.M., and Southard, J.B., 1996, Tempestite deposition: Journal of Sedimentary Research, v. 66, p. 875-887.

Ryer, T.A., and Anderson, P.B., 2004, Facies of the Ferron Sandstone, East-Central Utah, in Chidsey, T.C., Adams, R.D., and Morris, T.H, eds., Regional to Wellbore Analog for Fluvial-Deltaic Reservoir Modeling: The Ferron Sandstone of Utah: AAPG Studies in Geology 50, p. 59-93.

Walker, R.G., Duke, W.L., and Leckie, D.A, 1983, Hummocky stratification: Significance of its variable bedding sequences: Discussion and reply: Geological Society of America Bulletin, v. 94, p. 1,245-1,251. 